\title{
₹USGS
}

science for a changing world

Prepared for the National Aeronautics and Space Administration

\section{Geologic Map of Tooting Crater, Amazonis Planitia Region of Mars}

\author{
By Peter J. Mouginis-Mark
}

Pamphlet to accompany

Scientific Investigations Map 3297

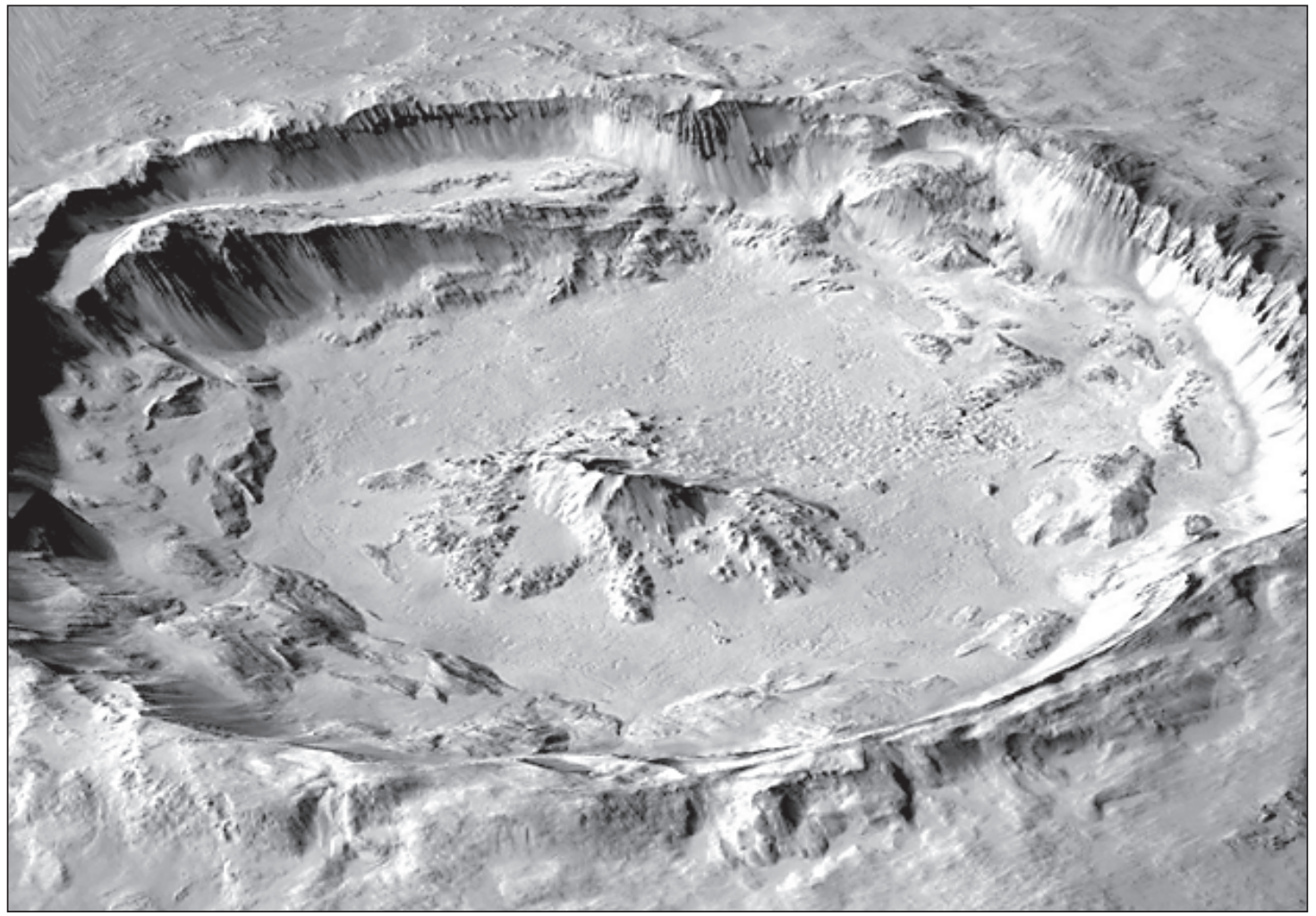

Tooting crater has a diameter of $27.2 \mathrm{~km}$ and formed on virtually flat lava flows within Amazonis Planita, Mars. The impact crater, which is located approximately 1,300 km west of the summit of Olympus Mons volcano, is very young and so provides a rare opportunity to map geomorphic units that are typically lost to erosion at older craters. Tooting crater is classified as a Multiple-Layered-Ejecta (MLE) crater. 



\section{Contents}

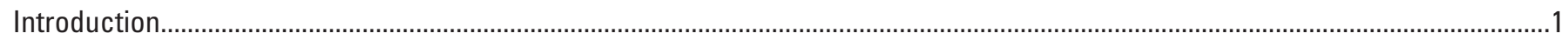

Origin of Crater Name

Data

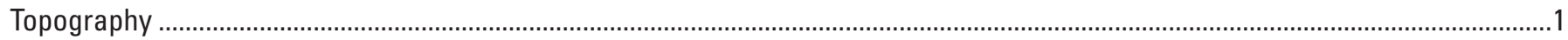

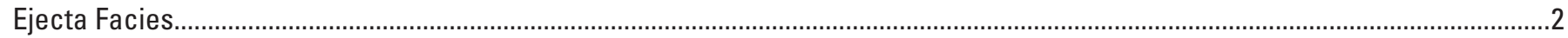

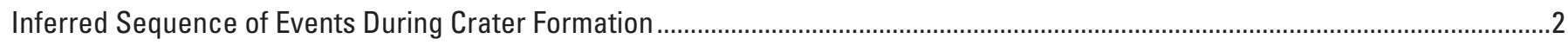

Acknowledgments

References Cited

\section{Tables}

1. HiRISE images available in March 2013 for Tooting crater, Mars ...............................................................................

2. Elevation information for Tooting crater, Mars. ...................................................................................................... 



\section{Introduction}

Since the earliest days of the Viking Orbiter missions, analysis of lobate deposits surrounding many Martian impact craters suggested the presence of water or ice within the top kilometer or more of the crust at the time of crater formation (Carr and others, 1977; Gault and Greeley, 1978; Mouginis-Mark, 1979). The terms "rampart crater" (Mouginis-Mark, 1978) and "single-layered", "double-layered", and "multi-layered ejecta craters" (Barlow and others, 2000) have been used to describe these craters. Details of the ejecta emplacement process may provide an understanding of the rheology of the flows and the flow process (Woronow, 1981; Baloga and others, 2005), as well as provide information on the possible interactions of target volatiles with impact melt generated during the event (Kieffer and Simonds, 1980; Mouginis-Mark, 1987). By virtue of its excellent degree of preservation and extensive coverage by high-resolution images, Tooting crater provides an outstanding opportunity to explore these relations.

Tooting crater $\left(23^{\circ} 10^{\prime}\right.$ N., $-152^{\circ} 10^{\prime}$ E.) formed within unit $\mathrm{Aa}_{3}$, interpreted by Scott and Tanaka (1986) as Late Amazonian lava flows. Tooting crater is very young, as is evident from the lack of large superposed impact craters on the ejecta layers. Using images from the High Resolution Imaging Science Experiment (HiRISE), Mouginis-Mark and Boyce (2012) made crater counts for several of the ejecta layers (units $\mathrm{el}_{3}, \mathrm{el}_{2}$, and $\mathrm{el}_{1}$ ) and derived an age for the Tooting impact of $\sim 2.9 \pm 0.3 \mathrm{Ma}$. The geologic units within which Tooting crater formed (described here as "target material") also has a young age, estimated to be 240 to $375 \mathrm{Ma}$ (Mouginis-Mark and Boyce, 2012), raising the possibility that Tooting crater may be the source crater for some of the basaltic shergottite meteorites, which have ejection ages of $2.4 \pm 0.2 \mathrm{Ma}$ to $3.0 \pm 0.3 \mathrm{Ma}$ and crystallization ages from $\sim 165 \pm 11$ Ma to $327 \pm 10 \mathrm{Ma}$ (McSween, 2008).

Tooting crater has a diameter of $27.2 \mathrm{~km}$ and formed on virtually flat lava flows within Amazonis Planitia $\sim 1,300 \mathrm{~km}$ west of the summit of Olympus Mons volcano (fig. 1), where there appear to have been no other major topographic features prior to the impact. The crater formed in an area $\sim 185 \mathrm{x} 135 \mathrm{~km}$ that is at an elevation between $-3,870 \mathrm{~m}$ and $-3,874 \mathrm{~m}$ relative to the Mars Orbiter Laser Altimeter (MOLA) Mars datum (Mouginis-Mark and Garbeil, 2007). This fortuitous situation (for example, a bland, horizontal target) allows the geometry of the crater and the thickness of the ejecta blanket to be accurately determined by subtracting the appropriate elevation of the surrounding landscape $(-3,872 \mathrm{~m})$ from the individual MOLA measurements across the crater. Thus, for the first time, it is possible to determine the radial decrease of ejecta thickness as a function of distance away from the rim crest (MouginisMark and Garbeil, 2007). On the basis of the four discrete ejecta layers surrounding the crater cavity, Tooting crater is classified as a Multiple-Layered-Ejecta (MLE) crater (Barlow and others, 2000). By virtue of the asymmetric distribution of secondary craters and the greater thickness of ejecta to the northeast, Morris and others (2010) proposed that Tooting crater formed by an oblique impact from the southwest. The maximum range of blocks that produced identifiable secondary craters is $\sim 500 \mathrm{~km}$ ( $\sim 36.0$ crater radii) from the northeast rim crest. In contrast, secondary craters are only identifiable $\sim 215 \mathrm{~km}$ (15.8 radii) to the southeast and $225 \mathrm{~km}$ (16.5 radii) to the west.

\section{Origin of Crater Name}

Tooting crater was formally named in 2005 by the International Astronomical Union. This name derives from the town of Tooting in South London, England. Tooting was first described back in the year 675 A.D., when it was called "Totinge." It was also mentioned in the Domesday Book in 1086. "Tooting" comes from the name of the Saxon Tota and follows the old English custom of adding "ing" (which means "the people who lived at") to the person's name. Thus "Tooting" literally means "The home of Tota's people."

\section{Data}

The primary data set used for the mapping came from the Thermal Emission Imaging System (THEMIS) visible (VIS) camera (Christensen and others, 2004). THEMIS VIS data at $18 \mathrm{~m} /$ pixel cover almost all of the mapped area, with only a few data gaps (fig. $2 A$ ) which were filled with THEMIS infrared (IR) data with $100 \mathrm{~m} /$ pixel resolution. Additional consulted data sets (fig. $2 B$ ) comprised images from the Context Camera (CTX) (Malin and others, 2007) and HiRISE (McEwen and others, 2007) with a ground sample distance of $\sim 6 \mathrm{~m} /$ pixel and $\sim 25 \mathrm{~cm} /$ pixel, respectively. Table 1 lists the HiRISE images used for the supplemental mapping of Tooting crater. Topographic data were derived from a digital elevation model (DEM) produced from stereo CTX images (MouginisMark and Boyce, 2012), controlled by MOLA spot elevation measurements (Smith and others, 2001).

\section{Topography}

Spot elevation measurements within Tooting crater (fig. 3, table 2) reveal that the maximum crater depth below the preimpact surface, $\sim 1,275 \mathrm{~m}$, is on the southern floor of the crater. The northern floor has a depth of $\sim 1,080 \mathrm{~m}$. The minimum rim elevation is $347 \mathrm{~m}$ above the pre-impact surface, and the maximum elevation is $951 \mathrm{~m}$. Thus the maximum depth/ diameter ratio of Tooting crater, as measured from the highest point on the rim to the lowest point of the floor, is $\sim 0.082$. The minimum depth/diameter ratio is 0.039 . The highest point on the central peak (unit cpm) is $1,110 \mathrm{~m}$ above the surrounding floor material, or $119 \mathrm{~m}$ below the pre-existing level of the target material and $768 \mathrm{~m}$ below the average rim crest elevation. 
Layering of the inner wall units observed in HiRISE images is interpreted by Mouginis-Mark and Boyce (2012) to be a sequence of uplifted lava flow units; the top of these units is at an elevation of $\sim 235-260 \mathrm{~m}$ above the pre-impact surface, implying that structural uplift of the target has produced

$\sim 30$ percent of the elevation of the rim crest.

Topographic data for the ejecta layers come from individual MOLA shots (Mouginis-Mark and Garbeil, 2007) and CTX stereo images controlled by the MOLA data (Mouginis-Mark and Boyce, 2012). The thickness of the ejecta layers decreases rapidly from the rim crest, where unit $r$ may be $\sim 550 \mathrm{~m}$ thick. In contrast, units $\mathrm{el}_{1}$ and $\mathrm{el}_{2}$ are typically $<5 \mathrm{~m}$ thick, which explains why numerous buried secondary craters can be identified within these units. The distal ramparts are typically 50-60 $\mathrm{m}$ high.

\section{Ejecta Facies}

The flow process was complex within each of the ejecta layers, as revealed by the four different facies within a single ejecta layer (compared to fig. 19 of Mouginis-Mark and Boyce, 2012). Crenulated, hummocky, and radial ejecta facies are indicated by symbols on the map. The remaining ejecta has a smooth appearance and is not specifically identified on the map. The near radial symmetry of the four layers suggests individual pulses of material sweeping out in all directions from the rim crest of Tooting crater. The smooth facies is interpreted to indicate uniform flow with no relative velocity gradient within the layer. The hummocky facies is interpreted to characterize areas where ejecta flow over-rode pre-existing topography within an earlier ejecta layer, disrupting the bland morphology of the ejecta layer. The radial facies is found down-range of discrete topographic obstacles such as large, partially buried secondary craters. The crenulated facies is predominately found close to the perimeter of the flow where the ejecta layer had continued to flow after the distal rampart (unit dr) had formed, causing a general disruption to the layer surface.

\section{Inferred Sequence of Events During Crater Formation}

Four episodes of emplacement for the discrete ejecta layers can be identified, but these episodes may have taken place almost simultaneously or separated by a very short period of time (perhaps only tens of seconds apart), as suggested by Osinski $(2004,2006)$ and Osinski and others (2004) for ejecta associated with the Ries crater (Germany) on Earth. Partially buried secondary craters with layers $\mathrm{el}_{1}$ and $\mathrm{el}_{2}$ reveal that the outer ejecta layers arrived at their maximum range after the ballistic component of the ejecta. Evidence for dewatering of the rim materials (unit $r$ ) after the ejecta came to rest has been documented for the southern rim (Morris and others, 2010; Mouginis-Mark and Boyce, 2012). Numerous small channels occur on the rim materials, and lobate flows, most likely composed of locally derived sediments, can be seen at the downslope ends of these channels. The origin and time of formation of the crater clusters remains enigmatic; these clusters comprise many tens of near circular craters a few tens of meters in diameter and are aligned in linear chains radial to the crater center. In places, crater clusters cross unit boundaries between $\mathrm{el}_{1}$ and $\mathrm{el}_{2}$, and in some places (such as to the northwest) cross onto the pre-impact surface (unit $\mathrm{Aa}_{3}$ ). Crater clusters can also be found that extend onto the distal ramparts. Thus the clusters appear to be late-stage features, except on the western margin where the craters appear to have been over-ridden by the distal ramparts associated with layer $\mathrm{el}_{1}$.

It is not possible to directly correlate events within the crater cavity and the formation of the ejecta layers, but undoubtedly both the interior and exterior units were formed almost simultaneously. Inside the cavity, pitted material (unit p) and smooth floor material (unit sf) were not deformed either by the uplift of the central peak or by the collapse of the terrace blocks to produce the wall blocks (unit wb) on the floor, so the period of cavity collapse that produced the wall blocks evidently pre-dated the formation of units $p$ and sf. Boyce and others (2012) have reviewed possible origins and proposed a model to explain the origin of the pitted material that included explosive degassing of water from previously emplaced waterbearing impact-rich breccia produced during the impact event. Smooth floor material (sf) overlays and embays some pitted material ( $p$ ) near the southern side of the floor. Smooth wall material (unit sw) formed late in the evolution of the crater, because this material wraps around many of the wall blocks (unit wb). At HiRISE resolution, this smooth material comprises flows that are interpreted to be remobilized by water leaking from the wall rocks (Morris and others, 2010; Mouginis-Mark and Boyce, 2012). Where the smooth wall material extends onto the crater floor, it overlies the pitted material. Flows also exist within the rim units; HiRISE images show materials interpreted to be impact melt deposits flowing around previously formed terrace blocks (Morris and others, 2010).

\section{Acknowledgments}

I thank James Skinner, Trent Hare, and Cory Fortezzo at the U.S. Geological Survey, Flagstaff, for significant assistance in the preparation of the digital version of this map. Kenneth Tanaka, Sarah Steward, and Dan Berman also provided valuable input. Ryan Luk produced the original THEMIS image mosaic used as the base map, and Philip R. Christensen facilitated the collection of these images. Joseph Boyce, Aisha Morris, and Harold Garbeil contributed to the ideas displayed on this map. This research was funded by the Planetary Geology and Geophysics Program, NASA grant NNX06AC61G. 


\section{References Cited}

Baloga, S.M., Fagents, S.A., and Mouginis-Mark, P.J., 2005, The emplacement of Martian rampart crater deposits: Journal of Geophysical Research, v. 110, E10001, doi:10.1029/ 2004JE002338.

Barlow, N.G., Boyce, J.M., Costard, F.M., and 6 others, 2000, Standardizing the nomenclature of Martian impact crater ejecta morphologies: Journal of Geophysical Research, v. 105 , p. $26,733-26,738$.

Boyce, J.M., Lionel, Wilson, Mouginis-Mark, P.J., Hamilton, C.W., and Tornabene, L.L., 2012, Origin of small pits in Martian impact craters: Icarus, v. 221, p. 262-275.

Carr, M.H., Crumpler, L., Cutts, J., and 3 others, 1977, Martian impact craters and emplacement of ejecta by surface flow: Journal of Geophysical Research, v. 82, p. 4055-4065.

Christensen, P.R., Jakosky, B.M., Kieffer, H.H., and 8 others, 2004, The Thermal Emission Imaging System (THEMIS) for the Mars 2001 Odyssey Mission: Space Science Reviews, v. 110 , p. $85-130$.

Gault, D.E., and Greeley, R., 1978, Exploratory experiments of impact craters formed in viscous targets-Analogs for Martian rampart craters: Icarus, v. 34, p. 486-495.

Kieffer, S.W., and Simonds, C.H., 1980, The role of volatiles and lithology in the impact cratering process: Reviews of Geophysics and Space Physics, v. 18, p. 143-181.

Malin, M.C., Bell, J.F., III, Cantor, B.A., and 11 others, 2007, Context Camera Investigation on board the Mars Reconnaissance Orbiter: Journal of Geophysical Research, v. 112, doi:10.1029/2006JE002808.

McEwen, A.S., Eliason, E.M., Bergstrom, J.W., and 12 others, 2007, Mars Reconnaissance Orbiter's High Resolution Imaging Science Experiment (HiRISE): Journal of Geophysical Research, v. 112, doi:10.1029/2005JE002605.

McSween, H.Y., 2008, Martian meteorites as crustal samples, in Bell, J.F., III, ed., The Martian surface-Composition, mineralogy, and physical properties: Cambridge, U.K., Cambridge University Press, p. 383-395.

Morris, A.R., Mouginis-Mark, P.J., and Garbeil, H., 2010, Possible impact melt and debris flows at Tooting crater, Mars: Icarus, v. 209, p. 369-389.
Mouginis-Mark, P.J., 1978, Morphology of martian rampart craters: Nature, v. 272, p. 691-694.

Mouginis-Mark, P.J., 1979, Martian fluidized crater morphology - Variations with crater size, latitude, altitude, and target material: Journal of Geophysical Research, v. 84, p. 8011-8022.

Mouginis-Mark, P.J., 1987, Water or ice in the martian regolith? Clues from rampart craters seen at very high resolution: Icarus, v. 71, p. 268-286.

Mouginis-Mark, P.J., and Boyce, J.M., 2012, Tooting craterGeology and geomorphology of the archetype fresh, large crater on Mars: Chemie der Erde Geochemistry, v. 72, p. 1-23.

Mouginis-Mark, P.J., and Garbeil, H., 2007, Crater geometry and ejecta thickness of the Martian impact crater Tooting: Meteoritics and Planetary Science, v. 42, p. 1615-1625.

Osinski, G.R., 2004, Impact melt rocks from the Ries structure, Germany-An origin as impact melt flows?: Earth and Planetary Science Letters, v. 226, p. 529-543.

Osinski, G.R., 2006, Effect of volatiles and target lithology on the generation and emplacement of impact crater fill and ejecta deposits on Mars: Meteoritics and Planetary Science, v. 41 , p. $1571-1586$.

Osinski, G.R., Grieve, R.A.F., and Spray, J.G., 2004, The nature of the groundmass of surficial suevite from the Ries impact structure, Germany, and constraints on its origin: Meteoritics and Planetary Science, v. 39, p. 1655-1683.

Scott D.H., and Tanaka, K.L., 1986, Geologic map of the western equatorial region of Mars. U.S. Geological Survey Miscellaneous Investigation Series Map I-1082-A, scale 1:15,000,000.

Smith, D.E., Zuber, M.T., Frey, H.V., and 21 others, 2001, Mars Orbiter Laser Altimeter-Experiment summary after the first year of global mapping of Mars: Journal of Geophysical Research, v. 106, p. 23689-23722.

Woronow, A., 1981, Pre-flow stresses in Martian rampart ejecta blankets-A means of estimating the water content: Icarus, v. 45 , p. $320-330$. 
Table 1. HiRISE images available in March 2013 for Tooting crater, Mars.

[Location number shown on figure 2]

\begin{tabular}{ccc}
\hline $\begin{array}{c}\text { Location } \\
\text { No. }\end{array}$ & HiRISE frame & $\begin{array}{c}\text { Stereo-HiRISE frame } \\
\text { (if available) }\end{array}$ \\
\hline 1 & ESP_012957_2030 & \\
2 & ESP_013023_2040 & ESP_013089_2040 \\
3 & ESP_013735_2035 & ESP_014157_2035 \\
4 & ESP_016135_2030 & ESP_016412_2030 \\
5 & ESP_016280_2045 & ESP_016425_2045 \\
6 & ESP_016346_2040 & \\
7 & ESP_017625_2040 & ESP_018258_2040 \\
8 & ESP_018759_2025 & ESP_019260_2025 \\
9 & ESP_019115_2035 & PSP_007907_2035 \\
10 & ESP_019893_2025 & \\
11 & ESP_020104_2030 & \\
12 & ESP_022227_2030 & \\
13 & ESP_022372_2045 & \\
14 & ESP_023717_2025 & \\
15 & ESP_028517_2030 & \\
16 & ESP_028583_2035 & \\
17 & ESP_030152_2030 & \\
18 & ESP_030218_2030 & \\
19 & PSP_001538_2035 & PSP_002158_2035 \\
20 & PSP_002013_2040 & \\
21 & PSP_002580_2035 & PSP_002646_2035 \\
22 & PSP_003569_2035 & PSP_005771_2035 \\
23 & PSP_003714_2030 & \\
24 & PSP_006193_2035 & PSP_007116_2035 \\
25 & PSP_006549_2035 & \\
26 & PSP_006760_2035 & PSP_007406_2035 \\
27 & PSP_007261_2035 & \\
28 & PSP_009766_2030 & PSP_009832_2030 \\
29 & PSP_009911_2035 & \\
30 & PSP_010333_2025 & PSP_010689_2025 \\
\hline & & \\
& & \\
\hline
\end{tabular}

Table 2. Elevation information for Tooting crater, Mars.

[Location numbers correlate with locations shown in figure 3. Elevations, relative to MOLA datum. Relative height is the height relative to the local datum $(-3,872 \mathrm{~m})]$

\begin{tabular}{|c|c|c|c|c|}
\hline $\begin{array}{c}\text { Location } \\
\text { No. }\end{array}$ & $\begin{array}{l}\text { Elevation } \\
\text { (m) }\end{array}$ & $\begin{array}{c}\text { Relative } \\
\text { height } \\
\text { (m) }\end{array}$ & $\begin{array}{c}\text { Unit } \\
\text { label }\end{array}$ & Setting \\
\hline 1 & $-3,990$ & -118 & $\mathrm{cpm}$ & Summit of central peak \\
\hline 2 & $-4,659$ & -787 & $\mathrm{cph}$ & Crest of hummocky peak \\
\hline 3 & $-4,887$ & $-1,015$ & wb & Small piece of wall block \\
\hline 4 & $-5,145$ & $-1,273$ & $\mathrm{p}$ & Lowest point on southern floor \\
\hline 5 & $-4,975$ & $-1,103$ & $\mathrm{p}$ & Western floor \\
\hline 6 & $-4,876$ & $-1,004$ & $\mathrm{p}$ & Northern floor \\
\hline 7 & $-4,865$ & -993 & $\mathrm{p}$ & Northern floor \\
\hline 8 & $-4,400$ & -528 & $w b$ & Wall block on eastern floor \\
\hline 9 & $-4,753$ & -881 & wb & Wall block on southern floor \\
\hline 10 & $-4,497$ & -625 & wb & Wall block on southern floor \\
\hline 11 & $-4,644$ & -772 & $w b$ & Wall block on western floor \\
\hline 12 & $-4,743$ & -871 & st & Southern end of terrace block \\
\hline 13 & $-3,730$ & 142 & $\mathrm{p}$ & Central part of terrace block \\
\hline 14 & $-3,963$ & -91 & $\mathrm{p}$ & Northern end of terrace block \\
\hline 15 & $-4,190$ & -318 & $w b$ & Slump block on northern wall \\
\hline 16 & $-4,367$ & -495 & $\mathrm{p}$ & Deposit on slump block on wall \\
\hline 17 & $-3,713$ & 159 & $\mathrm{p}$ & Deposit on slump block on wall \\
\hline 18 & $-3,305$ & 567 & $r$ & Northern rim crest \\
\hline 19 & $-2,985$ & 887 & $r$ & Eastern rim crest \\
\hline 20 & $-2,975$ & 897 & $r$ & Eastern rim crest \\
\hline 21 & $-3,433$ & 439 & $r$ & Tilted segment of southeast rim \\
\hline 22 & $-3,034$ & 838 & $r$ & Southeast rim crest \\
\hline 23 & $-3,682$ & 190 & $\mathrm{p}$ & Deposit on slump block on wall \\
\hline 24 & $-2,995$ & 877 & $r$ & Southern rim crest \\
\hline 25 & $-3,420$ & 452 & $r$ & Southwest rim crest \\
\hline 26 & $-3,269$ & 603 & $r$ & Western rim crest \\
\hline 27 & $-3,341$ & 531 & $r$ & Northwest rim crest \\
\hline 28 & $-3,068$ & 804 & $r$ & Northern rim crest \\
\hline 29 & $-3,570$ & 302 & $\mathrm{el}_{4}$ & Proximal part of ejecta layer \\
\hline 30 & $-3,564$ & 308 & $\mathrm{el}_{3}$ & Proximal part of ejecta layer \\
\hline 31 & $-3,700$ & 172 & $\mathrm{el}_{4}$ & Proximal part of ejecta layer \\
\hline 32 & $-3,833$ & 39 & $\mathrm{el}_{2}$ & Proximal part of ejecta layer \\
\hline 33 & $-3,755$ & 117 & $\mathrm{hr}$ & Block of rim material \\
\hline 34 & $-3,761$ & 111 & $\mathrm{el}_{4}$ & Proximal part of ejecta layer \\
\hline 35 & $-3,670$ & 202 & $\mathrm{el}_{4}$ & Proximal part of ejecta layer \\
\hline
\end{tabular}

